\title{
Effects of Clipping and Supplemental Nitrogen and Water on Loamy Upland Bluestem Range ${ }^{1}$
}

\author{
CLENTON E. OWENSBY, ROBERT M. HYDE, \\ AND KLING L. ANDERSON
}

Asst. Professor, Assoc. Professor, and Professor Emeritus respectively, Department of Agronomy, Kansas State University, Manhattan.

\section{Highlight}

Water and nitrogen were added separately and in combination to loamy upland bluestem range for four years. Plots were clipped at different dates. Moisture addition generally failed to increase total herbage yields, but supplemental nitrogen increased yields substantially. Nitrogen addition increased cool-season species in the stand. Moisture use was increased by nitrogen addition and reduced by clipping.

Moisture availability and nitrogen fertility have often been implicated as the principal environmental factors limiting herbage production in grasslands. In this study the relative importance of supplemental moisture and nitrogen for bluestem range, with attention to haying management, has been investigated.

Native prairie soils have a relatively fixed supply of nitrogen and a variable supply of rainfall (Jenny, 1930). Erratic herbage production due to variable precipitation may result in variable accumulation of nitrogen at different stages of the nitrogen cycle. For example, a series of years with above-normal precipitation could result in a tieup of nitrogen in a nonavailable organic form, or, conversely, a series of years with below-normal precipitation could result in a build-up of available nitrogen in the soil. Thus, production might not be directly associated with precipitation in a given year, and nitrogen fertilization might then be based on previous years' precipitation.

Use of nitrogen fertilizer has in-

\footnotetext{
${ }^{1}$ Contribution No. 1113. Department of Agronomy, Kansas Agricultural Experiment Station, Kansas State University, Manhattan. Received September 27, 1969; accepted for publication February 5, 1970.
}

creased the yield of herbage from True Prairie vegetation in the Kansas Flint Hills (Aldous, 1935; Huffine and Elder, 1960; Mader, 1956; Moser and Anderson, 1964). Herbage yield increases from nitrogen fertilization have approached economic feasibility, but changes in botanical composition to cool-season dominance have been a deterrent in application of this practice (Mader, 1956).

Nitrogen fertilizer also may be used to increase the protein content of native herbage (Aldous, 1935; Burzlaff et al., 1968; Gay and Dwyer, 1965; Mader, 1956; Moser and Anderson, 1965). Therefore, nitrogen fertilization of True Prairie grass herbage, which loses its crude protein content rapidly as it matures (Williams, 1953), results in higher quality forage.

In general moisture additions have been less effective in increasing herbage yields than have nitrogen additions (Klages and Ryerson, 1965; Smika et al., 1965). However, the combination of added nitrogen and added water has greatly increased herbage yields. Nitrogen addition also has increased moisture-use efficiency, perhaps in part because added nitrogen stimulates greater root exploration of the soil mass (McKell et al., 1962; Lorenz and Rogler, 1966).

Clipping, which removes transpiring tissue, reduces moisture use. Thus, Doss et al. (1966) in Texas reported that all species studied in their trials used more water prior to clipping than after clipping. A part of the reduction in moisture use, however, may be attributed to stoppage of root growth after clipping (Crider, 1955).

The work reported here evaluates the effects of added moisture and nitrogen on herbage yields, botanical composition, soil moisture, and herbage nitrogen percentage of bluestem range.

\section{Materials and Methods}

The study was conducted on a Truc Prairie loamy upland range described as ordinary upland by Anderson and Fly (1955) near Manhattan, Kansas. Since it was fenced in 1926 the plot site had been undisturbed and mulch accumulation was high. On April 25, 1965, standing vegetation was clipped to a 3inch stubble and removed. Precipitation for the area is shown in Figure 1.

The experimental design was a split-split plot replicated four times. Main plots were years, subplots were three clipping treatments, and sub-subplots were four nitrogen and moisture additions. The circular plots had diameters of 4.5 feet. In late April, 1965, bands of 16-gauge aluminum 6 inches wide were buried in the soil to a depth of 4 inches around these plots so that water could be added. All plots were banded, whether they received water or not.

Main plot treatments.

The experiment was conducted during 4 consecutive years, 1965 through 158 . Treatments remained the sanne on each plot throughout the experiment.

Subplot treatments.

Clipped once. Herbage was clipped to a 3 -inch stubble on October 1 of each year.

Clipped twice. Herbage was clipped to a 3-inch stubble on July 15 and October 1.

Clipped thrice. Herbage was clipped to a 3-inch stubble on July 15, August 15, and October 1 .

Sub-subplot treatments.

Nitrogen. Nitrogen as ammonium nitrate was broadcast at the rate of $50 \mathrm{lb} /$ acre on July 1 yearly.

Moisture. Water was added at irregular intervals (Table 1) sufficiently often in all mois- 


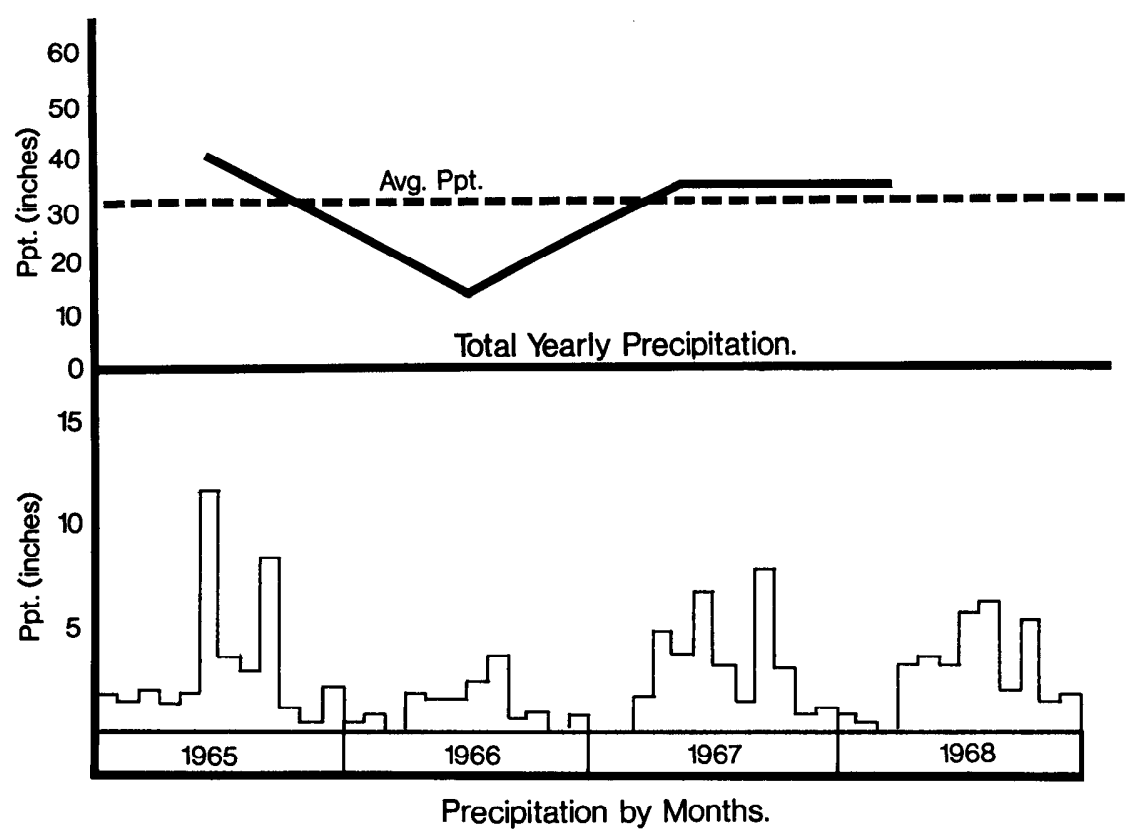

FIG. 1. Total precipitation by months and years from 1965 through 1968 at the Kansas State University Agronomy Farm, Manhattan.

ture plots to maintain adequate soil moisture during the entire 4-year period.

Moisture + nitrogen. Water and nitrogen were added as indicated in moisture and nitrogen treatments above.

Control. Neither moisture nor nitrogen was added.

Sample areas $\left(4.36 \mathrm{ft}^{2}\right)$ from each plot were clipped to 3 -inch stubble on dates previously indicated. Big bluestem (Andropogon gerardi Vitman) samples were taken at that time for Kjeldahl nitrogen determination (Hiller et al., 1948). Herbage was oven-dried and yields re-

Table 1. Herbage yields $\left(\mathrm{gm} / 4.36 \mathrm{ft}^{2}\right.$, oven-dry) October 1 from clippedtwice and clipped-thrice plots with different moisture and nitrogen treatments.

\begin{tabular}{lcc}
\hline \hline & \multicolumn{2}{c}{ Clipping } \\
\cline { 2 - 3 } Treatment & Twice & Thrice \\
\hline Nitrogen & 65 & 32 \\
Moisture & 78 & 39 \\
Moisture-plus-nitrogen & 88 & 38 \\
Control & 67 & 33 \\
LSD $_{.05}$ & 9 & 4 \\
\hline
\end{tabular}

ported on a dry-matter basis in grams per sample plot.

Botanical composition was determined by locating four $2 \times 5 \mathrm{dm}$ sample plots within each experimental plot. Plant stems originating at the soil surface were counted during mid to late June each year. Each stem was measured to the nearest square centimeter.

A neutron moisture probe, described by Van Bavel (1963), was used to take soil moisture readings as total soil moisture in all plots for each foot of a 5-foot soil profile. Sampling was twice monthly from April 1 to November 1 and once monthly during the remainder of the year.

Moisture-use efficiency was calculated as pounds of dry matter produced per inch of moisture incident on a given plot, based on precipitation from October 1 of the previous year to October 1 of the growing season. On plots with additional water that amount was added to the normal precipitation.

\section{Results and Discussion Herbage Yields}

Herbage yields (Fig. 2) were higher during the first year of the

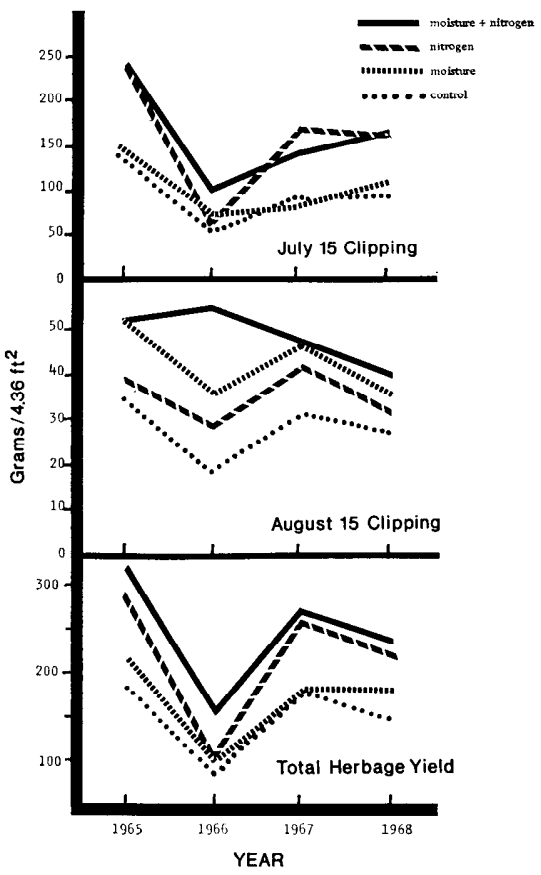

FIG. 2. Herbage yield (gm/4.36 ft ${ }^{2}$, ovendry) on July 15 and August 15, 196568 , and total herbage yield (includes Oct. 1 clipping) from plots with different moisture and nitrogen treatments.

experiment, 1965, than in other years. Even though natural precipitation was higher than normal in 1965, apparently some additional herbage increase was related to mulch removal prior to the beginning of the growing season. The following year, 1966, was extremely dry and yields on all plots were lower than in 1965. The addition of 18.5 inches of water to moisture plots failed to increase herbage yields unless additional nitrogen also was supplied. Another environmental factor must have been limiting in 1966; perhaps the higher than normal temperatures during July and August of that year prevented herbage yields from reaching those of 1965.

Contrary to expectations, moisture additions alone were generally not effective in increasing herbage yields. In 1965 herbage yields were increased on moisture-added plots above those of control plots, but in 1966 and 1967 no increases were obtained. Soil nitrogen carryover on control plots after dry 1966, indicated by higher percent nitrogen in 


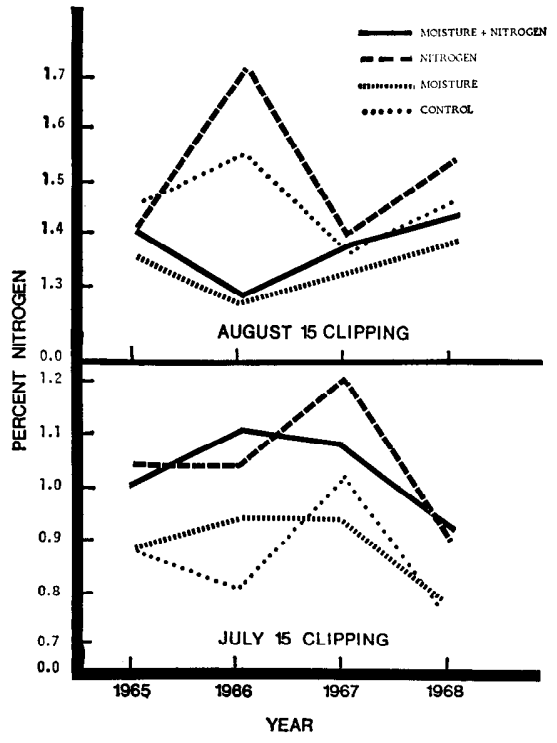

FIG. 3. Nitrogen (\%) in big bluestem forage on July 15 and August 15, 1965-68, from plots with different moisture and nitrogen treatments.

the forage for control plots in 1967 than in other years (Fig. 3), probably stimulated growth on control plots. No nitrogen carryover occurred on moisture plots, since moisture additions eliminated drought effects; therefore less nitrogen was available on moisture plots than on control plots in 1967 . In 1968 the increase in herbage production on moisture-added plots in relation to the control plots, together with similar nitrogen levels in the plants on moisture and control plots, indicates that in normal years moisture additions would increase herbage production, but not as much as would be produced by additional nitrogen.

Additional moisture appeared to be more effective in increasing herbagc yiclds during the latter part of the summer, evidenced by increased herbage yields on moisture plots above that of control plots and on moisture + nitrogen plots above that of nitrogen plots at the August 15 and October 1 clipping dates (Table 1).

Nitrogen addition generally increased herbage yields on plots with and without added water. Only in dry 1966 wcre yiclds on nitrogen plots less than were those of the

Table 2. Moisture-use efficiency (lb. dry matter/inch water) for different nitrogen and moisture treatments during 1965-68.

\begin{tabular}{lcccc}
\hline \hline & \multicolumn{4}{c}{ Years } \\
\cline { 2 - 5 } Treatment & 1965 & 1966 & 1967 & 1968 \\
\hline Nitrogen & 157 & 190 & 183 & 163 \\
Moisture & 108 & 61 & 102 & 100 \\
Moisture-plus-nitrogen & 151 & 97 & 151 & 131 \\
Control & 101 & 115 & 183 & 112 \\
\hline
\end{tabular}

control plots. Nitrogen addition increased moisture-use efficiency (Table 2), agreeing with the results of Lehman et al. (1968) in work with irrigated blue grama (Bouteloua gracilis Lag. ex Steud.).

Failure of moisture + nitrogen plots to produce much greater herbage yields than nitrogen plots in years with normal or above normal precipitation indicated that the nitrogen fertilization rate may not have been adequate on plots with supplemental water. Moisture-use efficiency, which was lower on moisture + nitrogen plots, substantiated that.

Plots clipped during July and August resulted in increased herbage production above that of plots clipped only at the close of the growing season. The 4 years of the study showed no reduction in herbage yield by following the July 15 hay cutting with an August clipping. Pressure exerted by clipping may not have been sufficient to influence herbage yields in the 4 years of the study. Cumulative effects over a longer period might have resulted in reductions in herbage yield due to the mid-August clipping following hay cutting on July 15.

Clipping during the growing season conserved moisture and increased moisture-use efficiency. Late season regrowth was increased by moisture additions and may have been partly responsible for higher moisture-use efficiency on plots clipped during the growing season.

\section{Percent Nitrogen}

Big bluestem herbage clipped on July 15 in 1965 and in 1968 showed higher nitrogen percentages on plots receiving additional nitrogen than on plots receiving only moisture or the control (Fig. 3). In 1966 percent nitrogen in big bluestem herbage on July 15 dropped below levels of 1965 in control plots. Moisture and nitrogen addition increased percent nitrogen in big bluestem plants on July 15 of that dry year (1966).

Reduced growth in 1966 apparently left soil-nitrogen levels higher than normal the following year on plots which did not receive additional water. Richardson (1935) inferred that in dry summers less of the readily available nitrogen in the soil was actually mobilized and used by plants. On July 15, 1967, the percent of nitrogen in big bluestem on control plots was higher than that in big bluestem on moisture plots, and the percent of nitrogen in big bluestem on nitrogen plots was higher than that in big bluestem on moisture + nitrogen plots. By 1968 the apparent imbalance had been negated and a pattern similar to the initial year was restored.

Mid-August nitrogen levels in 1965 in big bluestem regrowth on plots clipped July 15 indicated no difference in percent nitrogen due to moisture and nitrogen treatment (Fig. 3). In 1966, big bluestem regrowth from control and nitrogen plots had a much higher percent of nitrogen than that from moisture or moisture + nitrogen plots. That may have been due to a dilution effect, since regrowth herbage was higher on plots with additional moisture in 1966. Moisture and nitrogen treatments had little effect on the percent of nitrogen in big 
bluestem regrowth clipped in midAugust in 1967 and 1968.

At the close of each growing season moisture and nitrogen treatments had no effect on nitrogen levels in big bluestem. Big bluestem nitrogen levels on October 1 in 1966 were much higher than in other years, largely because of the higher nitrogen levels in big bluestem regrowth from plots clipped during the growing season.

Plots clipped twice during the growing season had higher nitrogen levels in big bluestem regrowth than had plots clipped once or not at all during the growing season. Apparently regrowth on plots clipped in mid-July had reached a stage of maturity at which nitrogen levels were similar to those on plots not clipped during the growing season.

\section{Soil Moisture}

Soil-moisture levels of nitrogen plots were generally lower than levels of control plots. Differences became greater as the growing season progressed, until mid-August when treatment effect lessened. In periods of limited precipitation moisture + nitrogen plots were usually lower in soil moisture than were moisture plots.

During periods of moisture stress, moisture levels were progressively lowered in the soil profile. That type of response was pointed out by Anderson (1965) in work with soil-moisture levels on burned plots and by Doss et al. (1962) in work with warm-season perennial forage species. Work by Dahlman (1968) in True Prairie supported that since water and nutrients in the lower portion of the soil profile would not be used until roots from the upper portion of the profile had grown into that area. Thus, those plants have no ability to use water in the lower portion of the soil profile until late in the growing season.

Clipping during the growing season reduced soil-moisture loss. Plots clipped in July had higher soil moisture late in the growing season than had plots not clipped during
Table 3. Basal cover $\left(\mathrm{cm}^{2} / 0.4 \mathrm{~m}^{2}\right)$ and total basal cover (\%) of decreaser species for different moisture and nitrogen treatments averaged over three clipping treatments.

\begin{tabular}{lccccc}
\hline \hline & \multicolumn{5}{c}{ Treatment } \\
\cline { 2 - 6 } & LSD $_{.05}$ & Nitrogen & Moisture & $\begin{array}{c}\text { Moisture }+ \\
\text { nitrogen }\end{array}$ & Control \\
\hline & \multicolumn{5}{c}{ Basal cover } \\
Decreasers & 32 & 223 & 257 & 255 & 241 \\
Big bluestem & 19 & 131 & 141 & 158 & 121 \\
Indiangrass & 14 & 68 & 92 & 86 & 76 \\
& & \multicolumn{5}{c}{ Total basal cover } & \\
Decreasers & 3.6 & 58.3 & 69.5 & 64.8 & 64.3 \\
Big bluestem & 4.8 & 35.5 & 39.5 & 41.2 & 34.3 \\
Indiangrass & 3.2 & 16.8 & 23.9 & 20.6 & 20.1 \\
\hline
\end{tabular}

the growing season. Plots clipped in July and August had higher soil moisture in early fall than had plots clipped in July and October and in October alone.

Effects on soil moisture of different clipping and moisture and nitrogen treatments were erased in most years by precipitation during the dormant period for the warmseason species. Only in 1967, following dry 1966, did treatment effects carry over, and they were confined to the lower portion of the soil profile. The fact that treatment effects were obliterated following seasons with normal precipitation indicated no cumulative effects on soil-moisture levels due to treatment over years.

\section{Plant Census}

Basal cover of decreasers-i.e., big bluestem, little bluestem ( $A n$ dropogon scoparius Michx.), and
Indiangrass (Sorghastrum nulans (L.) Nash)—varied widely from year to year during the study. Basal cover of most species increased during the first three years of the experiment. That may have been because mulch buildup was removed at the beginning of the 1965 growing season. Weaver and Rowland (1952) reported thinned stands resulting from heavy mulch buildup in True Prairie. They found that big bluestem made up $80 \%$ of the basal cover of the area and that little bluestem had essentially disappeared. Their work agreed with results of this experiment, in which little bluestem made up relatively little of the stand. Further increase in basal cover may have been due to nutrient carryover into 1967 from dry 1966. Basal cover of most species dropped in 1968. Percent composition of decreaser species during
Table 4. Basal cover $\left(\mathrm{cm}^{2} / 0.4 \mathrm{~m}^{2}\right)$ and total basal cover $(\%)$ for increaser species on plots with different moisture and nitrogen treatments.

\begin{tabular}{lrrcrc}
\hline \hline & LSD $_{.05}$ & Nitrogen & Moisture & $\begin{array}{c}\text { Moisture }+ \\
\text { nitrogen }\end{array}$ & Control \\
\cline { 3 - 6 } & \multicolumn{5}{c}{ Basal cover } \\
Increasers & 15 & 91 & 50 & 72 & 69 \\
Tall dropseed & 4 & 13 & 6 & 9 & 8 \\
Kentucky bluegrass & 16 & 53 & 23 & 40 & 30 \\
Sideoats gramma & 10 & 16 & 9 & 12 & 23 \\
& \multicolumn{5}{c}{ Total basal cover } \\
Increasers & 3.1 & 21.1 & 13.4 & 17.1 & 17.0 \\
Tall dropseed & 1.0 & 3.3 & 1.6 & 2.2 & 2.1 \\
Kentucky bluegrass & 2.2 & 11.4 & 5.9 & 9.1 & 7.4 \\
Sideoats grama & 1.6 & 3.9 & 2.2 & 2.9 & 5.1 \\
\hline
\end{tabular}


Table 5. Basal cover $\left(\mathrm{cm}^{2} / 0.4 \mathrm{~m}^{2}\right)$ of Kentucky bluegrass during 1965-68 on plots with different moisture and nitrogen treatments.

\begin{tabular}{lcccc}
\hline \hline & \multicolumn{4}{c}{ Treatment } \\
\cline { 2 - 5 } Year & Nitrogen & Moisture & $\begin{array}{c}\text { Moisture }+ \\
\text { nitrogen }\end{array}$ & Control \\
\hline 1965 & 11 & 8 & 11 & 8 \\
1966 & 32 & 27 & 29 & 37 \\
1967 & 88 & 23 & 48 & 31 \\
1968 & 82 & 34 & 72 & 42 \\
& LSD $_{.05}=36^{1}$ & & & \\
& $=33^{2}$ & & & \\
\hline
\end{tabular}

${ }^{1}$ LSD for differences due to nitrogen and moisture treatment within a year.

${ }^{2}$ LSD for year differences within a nitrogen and moisture treatment.

the 4 years of the study remained relatively stable.

Moisture addition stimulated increased basal cover of decreaser species on moisture and moisture + nitrogen plots above that of nitrogen plots but did not differ in basal cover of decreaser species from the control (Table 3). Percentage of total basal cover of decreaser species was lower on nitrogen plots than on the control plots, reflecting an increase in basal cover of increaser species (Table 4). Clipping treatments did not differentially affect hasal cover or percent composition of decreaser species.

Nitrogen addition resulted in increased basal cover of increaser species, i.c., Kentucky bluegrass (Poa pratensis L.), tall dropseed (Sporobolus asper (Michx.) Kunth), and sideoats grama (Bouteloua curtipendula (Michx.) Torr.). The principal increase came from Kentucky bluegrass (Table 4). Apparently addition of moisture on plots with added nitrogen slowed increases in Kentucky bluegrass basal cover (Table 5). That indicated nitrogen stimulated early-season growth of Kentucky bluegrass and subsequent early season use of soil moisture, which had the effect of lessening the competitive ability of the warmseason grass species. When moisture was added, that effect was lessened.

Clipping treatment did not affect increascr basal cover. Percentage of total basal cover of increasers followed the same trends as basal cover response in relation to treatments.

Perennial-forb basal cover was not affected by moisture and nitrogen treatment, but it increased on clipped thrice plots (Table 6). That may have been in response to increased pressure on the warm-season grasses clipped in mid-August. Many of the perennial forbs in this study had completed their life cycle before that clipping date and were probably unharmed by the clipping treatment. Percent composition of perennial forbs varied in much the same manner as did basal cover of that group.

Sedges (Carex L. spp.) increased in basal cover on plots with additional nitrogen. Most of the sedges encountered on those plots were cool-season species and would thus benefit from early-season additional nitrogen much the same as Kentucky bluegrass.

\section{Conclusions}

Increased dry-matter yields of 0.75 to 1.0 tons/acre on nitrogen plots above that of control plots in years of normal or above normal precipitation were shown. Moisture addition resulted in smaller yield

Table 6. Basal cover $\left(\mathrm{cm}^{2} / 0.4 \mathrm{~m}^{2}\right)$ and total basal cover (\%) of perennial forbs on plots with different clipping treatments.

\begin{tabular}{lcccc}
\hline \hline & \multicolumn{4}{c}{ Clipping treatment } \\
\cline { 2 - 4 } & LSD $_{.05}$ & Once & Twice & Thrice \\
\hline Basal cover & 10 & 25 & 20 & 35 \\
Percent composition & 2.1 & 7.0 & 4.7 & 7.9 \\
\hline
\end{tabular}
take advantage of that recovery. increases. Increased yields of herbage from nitrogen fertilization were shown in years of normal or abovenormal precipitation without the addition of water. Nitrogen fertilization also increased crude protein of the forage, and moisture-use efficiency was highest on nitrogen plots. Higher moisture use on nitrogen plots was not reflected in successive seasons.

The primary negative aspect of nitrogen fertilization was the insidious shift in composition toward cool-season species, which was probably aided by apparent nitrogen carryover from dry 1966. The slower shift toward Kentucky bluegrass in moisture + nitrogen plots resulted from more nitrogen use on those plots than on nitrogen plots in 1966 due to supplemental water. Greater nitrogen use resulted in less available nitrogen for cool-season species use in the following year on moisture + nitrogen plots.

Moisture-use efficiency and percent nitrogen in the forage indicated that nitrogen applied, and not used, in a dry year was not wasted. Some of that nitrogen apparently was recovered in the following season. Fertilization rates following a dry year probably should be lower than normal to

Shifts toward cool-season species tend to negate any favorable responses to nitrogen fertilization. Those shifts would result eventually in high percentages of Kentucky bluegrass, a species with low drought-tolerance and inherently lower productive capacity than the native warm-season species in True Prairie.

Use of nitrogen fertilization as a management tool in True Prairie must be held in abeyance until 
some economic means is found to control the shift to cool-season species. That means may well be properly-timed range burning or herbicide application.

\section{Literature Cited}

Aldous, A. E. 1935. Management of Kansas permanent pastures. Kansas Agr. Exp. Sta. Bull. 272. 44 p.

ANDERson, KLing L. 1965. Timc of burning as it affects soil moisture in an ordinary upland bluestem prairie in the Flint Hills. J. Range Manage. 18:311-316.

Anderson, Kling L., and C. L. Fly. 1955. Vegetation-soil relationships in Flint Hills bluestem pasturcs. J. Range Manage. 8:163-169.

BURZLAFF, D. F., G. W. FICK, AND L. R. Ritienhouse. 1968. Effect of nitrogen fertilization on certain factors of a western Nebraska range ecosystem. J. Range. Manage. 21:21-23.

Crider, F. J. 1955. Root growth stoppage resulting from defoliation of grass. U.S. Dep. Agr. Tech. Bull. 1102. $22 \mathrm{p}$.

Dahlman, R. C. 1968. Root production and turnover of carbon in the root-soil matrix of a grassland ecosystem. U.S.S.R. Acad. Sci. Int. Symp. on Methods of Productivity Studies in Root Systems and Rhizosphere Organisms. Publishing House "Nauka," Leningrad Branch, U.S.S.R. Doss, B. D., D. A. Ashley, O. L. BeNnett, and R. M. Patterson. 1966.
Interactions of soil moisture, nitrogen, and clipping frequency on yield and nitrogen content of coastal bermudagrass. Agron. J. 58:510-512.

GAY, C. W., AND D. D. DWYer. 1965. Effect of one year's nitrogen fertilization on native vegetation under clipping and burning. J. Range Manage. 18:273-276.

Hiller, A., J. Plazin, and D. D. Van SLYKe. 1948. A study of conditions for Kjeldahl determination of nitrogen in proteins. J. Biol. Chem. 176:1401-1420.

Huffine, W. W., and W. C. Elder. 1960. Effect of fertilization on native grass pastures in Oklahoma. J. Range Manage. 13:34-36.

Jenny, Hans. 1930. A study of the influence of climate upon the nitrogen and organic matter content of the soil. Missouri Agr. Exp. Sta. Res. Bull. 152. $66 \mathrm{p}$.

KLAGes, M. G., AND D. E. Ryerson. 1965. Effect of nitrogen and irrigation on yield and botanical composition of western Montana range. Agron. J. 57:78-81.

Lehman, O. R., J. R. Bond, and H. V. EcK. 1968. Forage potential of irrigated blue grama with nitrogen fertilization. J. Range Managc. 21:7173.

LoRenz, R. J., ANd G. A. Rogler. 1966. Root growth of northern plains grasses under various fertilizer and management treatments. Proc. Amer. Forage and Grassland Council. I-11.
Mader, E. L. 1956. The influence of certain fertilizer treatments on the native vegetation of Kansas Prairie. Ph.D. Diss. Univ. of Nebr. $116 \mathrm{p}$.

Moser, L. E., ANd K. L. Anderson. 1964. Nitrogen and phosphorus fertilization of bluestem range. Trans. Kansas Acad. Sci. 67(4):613-616.

MaKell, C. M., M. B. Jones, ANd E. R. Perrier. 1962. Root production and accumulation of root material on fertilized range. Agron. J. 59:459461.

Richardson, H. L. 1935. The nitrogen cycle in grassland soils. Trans. Third Int. Cong. of Soil Sci. 1:219 221.

Smika, D. E., H. J. HaAs, and J. F. Power. 1965. Effects of moisture and nitrogen fertilizer on growth and water use by native grass. Agron. J. 57:483-486.

Van Bavel, C. H. M. 1963 . Neutron scattering measurement of soil moisture: development and current status. Proc. Int. Symp. on Humidity and Moisture. Washington, D.C., May 20-23, 1963.

Williams, John S. 1953. Seasonal trends of minerals in prairie grasses. J. Range Manage. 6:100-108.

Weaver, J. E., and N. W. Rowland. 1952. Effects of excessive natural mulch on development, yield, and structure of native grassland. Bot. Gaz. 114:11-19.

\section{BALLOTS AND DUES}

Ballots and dues notices are mailed to all members of the Society on October I each year. This year the membership is asked to vote not only for a president elect and two new directors, but also on several proposed changes in ASRM's Articles of Incorporation. The candidates and the proposed changes are presented in the August and October issues of Rangeman's News: please read this material carefully, then return your ballots before November 30, 1970 .

1971 dues are payable on or before January 1, 1971. Effective support of the Society can best be demonstrated by a prompt return of both ballots and dues payments. 